\title{
DAMPAK COVID-19 TERHADAP PENDAPATAN PENJUAL DAGING AYAM BROILER DI PASAR SILA KABUPATEN BIMA
}

\section{IMPACT OF COVID-19 ON INCOME OF BROILER CHICKEN MEAT SELLERS AT SILA MARKET, BIMA REGENCY}

\author{
Ria Harmayani ${ }^{1}$, Ni Made Andry Kartika ${ }^{2}$, dan M. Nur Aditya ${ }^{3}$ \\ Program Studi Ilmu Peternakan, Fakultas Peternakan, Universitas Nahdlatul Wathan Mataram, \\ Jl. Kaktus, No. 1-3 Gomong-Mataram, Nusa Tenggara Barat, Indonesia. \\ riaharmayani@gmail.com
}

\begin{abstract}
ABSTRAK
Penelitian survey bertujuan untuk mengetahui pendapatan penjual daging ayam broiler di Pasar Sila Kabupaten Bima, dilaksanakan selama dua bulan dari bulan Agustus sampai September 2020. Responden sebanyak 10 orang penjual atau semua pedagang daging ayam broiler di Pasar Sila. Analisa data dalam penelitian ini yaitu semua data hasil penelitian dianalisa deskriptif. Variabel yang diamati meliputi variabel independen yaitu biaya tetap, biaya tidak tetap, penjualan, pendapatan dan Break Even Point/BEP dan variabel dependen yaitu usia, pendidikan, tanggungan keluarga, dan pengalaman berdagang. Hasil penelitian menunjukan bahwa pendapatan penjual daging ayam broiler sesudah pandemi di Pasar Sila Kabupaten Bima masih dalam kondisi baik, sehingga dapat dikatakan bahwa usaha penjual daging ayam broiler berada pada posisi yang menguntungkan dan tidak memberikan dampak signifikan. Pendapatan bersih daging ayam broiler sebelum pandemi yaitu sebanyak Rp.7.300.000/bulan dan pendapatan bersih usaha daging ayam broiler sesudah pandemi yaitu sebanyak Rp. 8.915.000/bulan.BEP harga daging ayam broiler sebelum pandemi yaitu sebanyak Rp. 1.076.510/hari, sedangkan BEP harga daging ayam broiler sesudah pandemi yaitu sebanyak Rp. 1.387.793/hari. Diharapkan kepada pemerintah dan dinas terkait dapat melakukan sosialisasi dan pembaharuan informasi secara rutin yang berkaitan dengan penjualan ayam broiler pada saat pandemi Covid-19 serta diharapkan kepada penjual maupun pembeli di Pasar Sila untuk selalu mematuhi penerapan prokes dalam usaha meminimalisir penularan dan terbentuknya kluster baru Covid-19.
\end{abstract}

Kata kunci : Dampak Covid-19; Pendapatan Penjualan; Ayam Broiler; Pasar Sila.

\section{ABSTRACT}

The survey research aims to determine the income of broiler chicken sellers at Sila Market, Bima Regency, carried out for two months from August to September 2020. The respondents were 10 sellers or all broiler meat traders in Sila Market. Analysis of the data in this study, namely all research data were analyzed descriptively. The observed variables include independent variables, namely fixed costs, variable costs, sales, income and Break Even Poin/BEP and the dependent variables are age, education, family dependents, and trading experience. The results showed that the income of broiler meat sellers after the pandemic at Sila Market, Bima Regency was still in good condition, so it can be said that the broiler meat seller's business was in a profitable position and did not have a significant impact. The net income of broiler chicken before the pandemic was Rp. 7,300,000/month and the net income of broiler meat business after the pandemic is Rp. 8,915,000/month. BEP the price of broiler chicken before the pandemic was Rp. 1,076,510/day, while the BEP price of broiler chicken after the pandemic is Rp. 1,387,793/day. It is hoped that the government and related agencie 
can carry out regular socialization and updating of information relating to the sale of broiler chickens during the Covid-19 pandemic and it is hoped that sellers and buyers at Sila Market will always comply with the implementation of health procedures in an effort to minimize transmission and the formation of new clusters of Covid-1919.

Keywords: Broiler Chicken; Impact of Covid-19; Market please; Sales revenue.

\section{Pendahuluan}

Pandemi Covid-19 menjadi masalah kesehatan dunia yang ditetapkan sejak 11 Maret 2020. Kasus ini berawal berdasarkan informasi dari World Health Organization (WHO) sejak 31 Desember 2019 yang menyebutkan adanya kasus kluster pneumonia dengan etiologi yang tidak jelas di Kota Wuhan, Provinsi Hubei, Cina. Lalu, kasus ini terus berkembang hingga adanya laporan kematian dan terjadi importasi di luar Cina. Pada tanggal 30 Januari 2020, WHO menetapkan Covid-19 sebagai Public Health Emergencyof InternationalConcern (PHEIC) atau Kedaruratan Kesehatan Masyarakat yang meresahkan Dunia Pada tanggal 12 Februari 2020, WHO resmi menetapkan penyakit virus Corona pada manusia ini dengan sebutan Corona virus Disease (Covid-19). Di Indonesia, Covid-19 dilaporkan sejak 2 Maret 2020. Virus Corona diketahui adalah virus yang menyebabkan penyakit mulai dari gejala ringan sampai berat.Terdapat dua jenis virus corona yang menyebabkan dan menimbulkan penyakit gejala berat seperti Middle East Respiratory Syndrome (MERS) dan Severe Acute Respiratory Syndrome/ SARS (WHO, 2020).

Munculnya Covid-19 di Inonesia menyebabkan pemerintah Indonesia bertindak tegas dengan menghimbau masayarakat untuk tidak melakukan aktivitas diluar rumah sebagai upaya untuk menghindari meningkatnya penyebarannya, melakukan social distancing dan Pembatasan Sosial Berskala Besar sampai kehidupan bermasyarakat dengan kebiasaan normal baru. Hingga saat ini, masyarakat Indonesia secara umum sudah masih mengikuti dan mematuhi perintah yang diberikan pemerintah meskipun masih banyak pelanggaran yang terjadi. Kebijakan tersebut memunculkan permasalahan yang dirasakan masayarakat dari berbagai kalangan baik kalangan atas, menengah dan bawah.Namun, tentu saja kalangan bawah merasakan dampak yang begitu besar, karena kesulitan dalam mencari nafkah dan kesulitan untuk mendapatkan alat pencegahan Covid-19 seperti handsanitizer dan masker sehingga mereka mudah terkena virus hingga dapat menyebabkan kematian(WHO, 2020).

Selain itu, sejak Maret 2020, pemerintah juga mulai mengeluarkan kebijakan Work From Home (WFH) yang menyebabkan banyak kegiatan ekonomi yang mengalami dampak buruk, salah satunya adalah para peternak ayam. Hasil temuan para peternak ayam mengalami kerugian karena sektor yang menyerap hasil ternak ayam mulai tidak beroperasi, seperti restoran-restoran, pasar, hotel, usaha katering dan usaha-usaha yang berkaitan dengan pengolahan daging ayam. Hal tersebut disebabkan kebijakan yang berkaitan dengan pembatasan kegiatan untuk pencegahan penyebaran virus corona.

Permasalahan kerugian yang dialami para peternak ayam tersebut disebabkan oleh penumpukan ayam dikandang, sementara permintaan pasar menurun drastis, sehingga terjadi kelebihan produksi (oversupply) dan menyebabkan terjadinya penurunan harga yang signifikan. Hingga saat ini, pemerintah tidak melakukan tindakan untuk mengatasi permasalahan harga jual ayam yang di bawah harga acuan. Ayam yang tidak dapat dijual dan terus berada di kandang menyebabkan para peternak harus memberi makan dan vitamin supaya ayam tetap bisa hidup. Namun, hal itu sulit dilakukan karena peternak ayam tidak memiliki pemasukan atas penjualan ayam. Peternak mengalami over-cost, pembiayaan yang semakin melambung. Dari sisi aturan hukum, kerugian para peternak ayam tersebut dapat dihindari apabila pemerintah melakukan intervensi berdasarkan Pasal 3 ayat (1) 
Permendagri Nomor 7 Tahun 2020 Tentang Harga Acuan Pembelian di Tingkat Petani dan Harga Acuan Penjualan di Tingkat Konsumen. Hal tersebut berdampak pada pendapatan penjual daging ayam broiler di Pasar Sila Kabupaten Bima sehingga perlu dilaksanakan penelitian ini untuk mengetahui dampak Covid-19 terhadap pendapatan penjual daging ayam broiler di Pasar Sila Kabupaten Bima.

\section{Metode Penelitian}

Penelitian ini dilaksanakan di Pasar Sila, Kecamatan Bolo, Kabupaten Bima, Provinsi Nusa Tenggara Barat selama 2 bulan dari bulan Agustus sampai September2020. Penelitian ini dilaksanakan dengan metode survey dengan melakukan observasi dan wawancara langsung kepada responden dengan menggunakan kuesioner yang telah dipersiapkan. Responden yang digunakan sebanyak 10 orang penjual atau semua pedagang daging ayam broiler di Pasar Sila.

Data dan sumber data dalam penelitian ini meliputi data primer dan sekunder. Data primer dikumpulkan melalui wawancara langsung dengan penjual responden yang dibantu dengan daftar pertanyaan (kuesioner) yang telah disediakan. Sedangkan data sekunder dikumpulkan dari instansi-instansi pemerintah terkait. Analisa data dalam penelitian ini yaitu semua data primer dan data sekunder dianalisa deskriptif.Variabel yang diamati meliputi variabel independen yaitu biaya tetap, biaya tidak tetap, penjualan, pendapatan dan Break Even Point/ $B E P$ dan variabel dependen yaitu usia, pendidikan, tanggungan keluarga, dan pengalaman berdagang.

Model analisis data yang digunakan dalam penelitian ini adalah sebagai berikut :

\section{a. Biaya Total / Total Cost}

Analisa data untuk biaya total dihitung berdasarkan rumus penghitungan biaya total Rosyidi (2001), yaitu sebagai berikut:TC $=$ TFC + TVC

Keterangan : $\mathrm{TC}=$ Total Cost $/$ Biaya Total $(\mathrm{Rp})$
TFC $=$ Total Fixed Cost/Biaya Tetap Total (Rp)

TVC $=$ Total VariabelCost/Biaya Variabel Total (Rp)

\section{b. Total Penerimaan / Total Revenue}

Total Penerimaan adalah produksi dikali dengan harga yang berlaku, dihitung berdasarkan Syarifuddin (1995):

$$
\mathbf{T R}=\mathbf{Q} \times \mathbf{P Q}
$$

Keterangan :

$\mathrm{TR}=$ Total Revenue/Penerimaan Total $(\mathrm{Rp})$

$\mathrm{Q}=$ Jumlah Produksi $(\mathrm{Kg})$

$\mathrm{PQ}=$ HargaJual $(\mathrm{Rp} / \mathrm{Kg})$

\section{c. Pendapatan}

Setelah penerimaan diketahui, maka dapat pula diketahui pendapatan adalah penerimaan dikurangi dengan biaya total, dihitung berdasarkan Syarifuddin (1995):

Keterangan:

$$
\pi=\mathbf{T R}-\mathbf{T C}
$$

$\pi=$ Profit/Keuntungan ( $\mathrm{Rp})$

$\mathrm{TR}=$ Total Revenue/Penerimaan Total $(\mathrm{Rp})$

$\mathrm{TC}=$ Total Cost/Biaya Total $(\mathrm{Rp})$

\section{d. Break Evet Point/ BEP}

Penentuan besarnya titikimpas (Break Even Point) berdasarkan BEP produksi dan BEP harga, dihitung berdasarkan rumus Soekartawi (2006):

\section{BEP Produksi $=$ TC/PQ}

Keterangan :

$\mathrm{TC}=$ Total Cost (biaya total)

$\mathrm{PQ}=$ Harga Jual (rupiah/ ekor)

Keterangan :

BEP Harga $=$ TC/Q

$\mathrm{TC}=$ Total Cost (biaya total)

$\mathrm{Q}=$ Produksi (ekor)

\section{e. Definisi Operasional}

1. Produksi adalah jumlah ayam pedaging yang dihasilkan oleh penjual/pedagang.

2. Harga produksi merupakan harga jual ayam di tingkat pedagang.

3. Penerimaan adalah pendapatan yang diperoleh dari hasil penjualan produk 
4. Biaya tidak tetap yaitu biaya yang berubah sesuai dengan jumlah produksi yang dihasilkan

5. Biaya tetap yaitu biaya yang dikeluarkan yang besarnya tidak terkait langsung dengan jumlah produksi.

6. Biaya total yaitu gabungan biaya tetapdengan biaya tidak tetap.

7. Pendapatan bersih (Keuntungan) adalah selisih antara penerimaan dengan biaya total.

8. Break Even Point (BEP)yaitu suatu alat perencanaan penjualan, sekaligus perencanaan tingkat produksi, agar suatu usaha secara minimal tidak mengalami kerugian. Satuan yang digunakan adalah BEP produksi dan BEP harga.

\section{Hasil dan Pembahasan}

\section{Pasar Sila dan Kegiatan Usaha Penjual Daging Ayam Broiler}

Pasar Sila merupakan salah satu pasar tradisional yang berada di Kecamatan Bolo, Kabupaten Bima, Provinsi Nusa Tenggara Barat.Pasar Sila ini menyediakan kebutuhan pokok serta bahan makanan lainnya. Pasar sila memiliki batas-batas sebagai berikut:

Sebelah Utara : Dusun Rato Sebelah Selatan : Dusun Kamposigi Sebelah Barat : Dusun Dorowila Sebelah Timur:Dusun Saleko

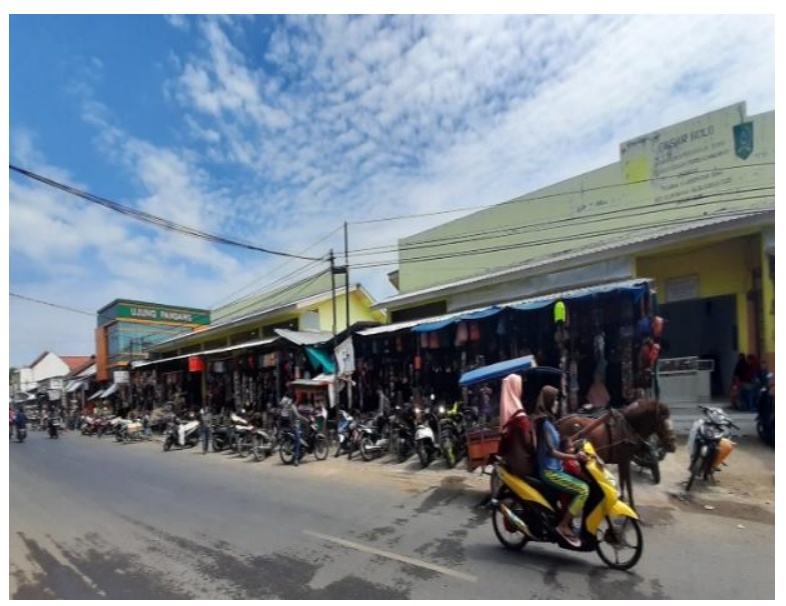

Gambar 1. Pasar Sila Kecamatan Bolo Kabupaten Bima
Pasar Sila termasuk pasar yang paling besar di Kecamatan Bolo dengan luas tanah $5.850 \mathrm{~m}^{2}$.Pasar sila adalah pasar tradisional yang berada di Kecamatan Bolo yang dimana tempatnya sangat strategis. Pasar sila ini juga satu-satunya pasar sentral dari beberapa pasar yang ada di wilayah Bima. Keberhasilan pengembangan Pasar Sila karena lokasinya yang strategis, inovasi dan peningkatan efisiensi yang lebih baik serta pemasaran yang banyak dikunjungi oleh beberapa kalangan masyarakat. Selain itu, Pasar Sila juga masuk ke dalam kategori Pasar Aman Berbasis Komunitas dan diperhatikan BPOM dalam mewujudkan pasar dengan pangan yang aman (BPOM NTB, 2021).

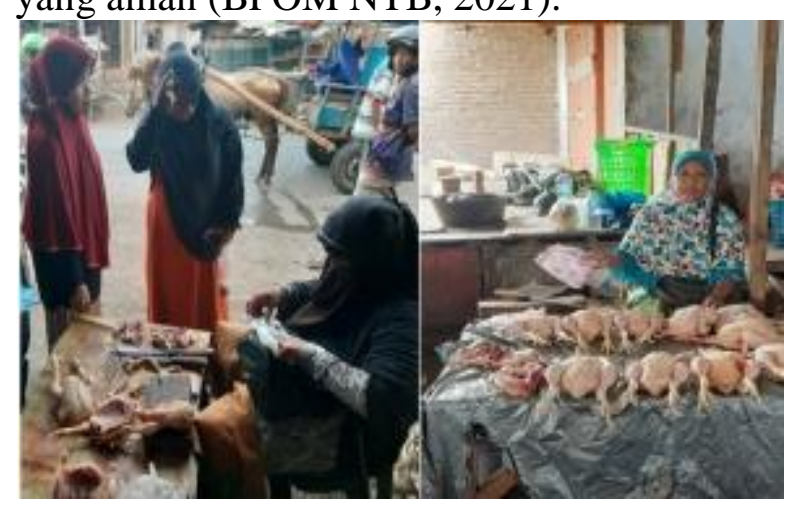

Gambar 2. Penjual daging ayam broiler di Pasar Sila

Pemasaran dan pola distribusi ayam broiler di Kabupaten Bima ini pada umumnya terbentuk sendiri. Berdasarkan hasil penelitian menunjukkan bahwa terdapat beberapa tingkatan lembaga pemasaran yang menjadi satu saluran yang dimulai dari peternak ayam broiler, pedagang pengumpul, pedagang besar, penjagal, pedagang eceran hingga ke konsumen. Dalam hal ini ternak berbentuk hidup ataupun potongan seperti daging. Kegiatan usaha pedagang pengumpul yaitu mendatangi peternak yang ada di setiap desa bahkan setiap kecamatan, kemudian menjualnya ke pedagang besar. Pedagang besar biasanya melakukan pembelian ternak langsung dari peternak atau dari pedagang pengumpul tergantung dari informasi yang didapatkan kemudian melakukan pengiriman ternak ayam broiler keluar daerah seperti Sila, Pena To'i, dan Sambi Na'e. Penjagal 
dan Pedagang eceran hampir sebagian besar sebagai pedagang pemotong yang pembelian ternaknya dari peternak, pedagang pengumpul, dan pedagang besar kemudian memotong ternak ayam broiler tersebut di rumah potong unggas setempat atau melakukan pemotongan sendiri (BPS, 2018).

\section{Data Responden Penjual Daging Ayam Broiler Di Pasar Sila}

Tabel 1. Usia Responden

\begin{tabular}{ccc}
\hline $\begin{array}{c}\text { Usia Responden } \\
\text { (Tahun) }\end{array}$ & $\begin{array}{c}\text { Jumlah } \\
\text { Responden } \\
\text { (Orang) }\end{array}$ & $\begin{array}{c}\text { Presentase } \\
(\%)\end{array}$ \\
\hline $36-40$ & 0 & 0 \\
$41-45$ & 5 & 50 \\
$46-50$ & 5 & 50 \\
Jumlah & 10 & 100 \\
\hline
\end{tabular}

Sumber : Data Primer Diolah (2020).

Berdasarkan tabel 1 diatas, dapat diketahui bahwa sebagian besar responden berusia 41- 45 tahun yaitu sebanyak 5 orang (50\%) dan usia 46-50 tahun yaitu sebanyak 5 orang (50\%). Depkes RI (2009) menyebutkan bahwa usia produkif adalah antara 15 - 54 tahun. Menurut Depkes RI klasifikasi umur digolongkan menjadi 3 antara lain masa dewasa awal (26 - 35 tahun), masa dewasa akhir (36 - 45 tahun), dan masa lansia awal (46 - 55 tahun).

Dalam penelitian ini umur responden yang diteliti adalah umur 41-50 tahun, sehingga usia tersebut masih termasuk usia kerja yang produktif. Peran faktor umur memberikan respon terhadap situasi yang potensial menimbulkan stress. Tenaga kerja yang usianya sudah lanjut ( $>60$ tahun) maka kemampuan dalam beradaptasinya menurun karena adanya penurunan fungsi organ di dalam tubuhnya (Roestam, 2003).

Tabel 2. Pendidikan Responden

\begin{tabular}{ccc}
\hline Pendidikan & $\begin{array}{c}\text { Jumlah } \\
\text { Responden } \\
\text { (Orang) }\end{array}$ & $\begin{array}{c}\text { Presentase } \\
(\boldsymbol{\%})\end{array}$ \\
\hline SD & 0 & 0 \\
SMP & 4 & 40 \\
SMA & 4 & 40 \\
S1 & 2 & 20 \\
Jumlah & 10 & 100 \\
\hline
\end{tabular}

Sumber : Data Primer Diolah(2020).

Berdasarkan tabel 2 diatas, dapat diketahui bahwa sebagian besar responden pendidikan SMP sebanyak 4 orang (40\%), pendidikan SMA sebanyak 4 orang (40\%) dan pendidikan S1 sebanyak 2 orang (20\%). Pada dasarnya orang yang berpendidikan akan terhindar dari kebodohan dan kemiskinan, karena dengan modal ilmu yang diperolehnya melalui proses pendidikan, orang akan mampu mengatasi masalah kehidupan yang dihadapinya. Semakin tinggi pendidikan maka semakin tinggi pengetahuan, keterampilan dan kemampuannya (Nugroho, 2008). Hal ini sebagaimana dikemukakan oleh Notoatmodjo (2012) bahwa tingkat pendidikan seseorang berpengaruh dalam memberikan respon terhadap sesuatu yang datang dari luar.

Pendidikan merupakan suatu proses secara sadar dalam mengembangkan potensi, bakat dan kemampuan-kemampuan untuk mewujudkan tujuan yang telah ditetapkan sesuai dengan keperluan dirinya sendiri, masyarakat, bangsa, dan negara. Adapun tiga jenis jalur pendidikan, yaitu pendidikan formal, informal dan nonformal. Ketiga jenis pendidikan ini saling bersinergi dan alangkah baiknya ketiganya dipenuhi oleh masingmasing orang untuk hasil yang maksimal. Dengan adanya pendidikan yang baik maka akan meningkatkan cara berpikir seseorang menuju kearah yang lebih berkembang dan akan lebih maju. Lewat pendidikan kita bisa menjawab tantangan hidup masa sekarang dan mulai merencanakan untuk masa yang akan datang. Pendidikan akan dapat membawa kita ke dalam perubahan yang sangat berarti dalam hidup, baik masa sekarang maupun masa yang akan datang.

Tabel 3. Tanggungan Keluarga Responden

\begin{tabular}{ccc}
\hline $\begin{array}{c}\text { Tanggungan } \\
\text { Keluarga } \\
\text { (Orang) }\end{array}$ & $\begin{array}{c}\text { Jumlah } \\
\text { Responden } \\
\text { (Orang) }\end{array}$ & $\begin{array}{c}\text { Presentase } \\
(\%)\end{array}$ \\
\hline $1-3$ & 4 & 40 \\
$4-6$ & 6 & 60 \\
Jumlah & 10 & 100 \\
\hline
\end{tabular}

Sumber : Data Primer Diolah (2020).

Berdasarkan tabel 3 diatas, dapat diketahui bahwa sebagian besar responden 
yang memiliki anggota tanggungan keluarga terendah terhitung sebanyak 1-3 orang dengan jumlah responden 4 orang (40\%) sedangkan anggota tanggungan keluarga tertinggi terhitung sebanyak 4-6 orang dengan jumlah responden 6 orang $(60 \%)$. Tanggungan keluarga berpengaruh signifikan terhadap pendapatan. Semakin banyak tanggungan keluarga, maka akan semakin menurun pendapatan. Semakin banyak jumlah anggota keluarga maka akan semakin banyak kebutuhan hidup keluarga yang harus dipenuhi (Rangkuti, dkk. 2014).

Menurut Rangkuti,dkk.

menyatakan bahwa jumlah tanggungan berdasarkan golongan hanya ada dua kelompok yaitu tanggungan keluarga kecil dan tanggungan keluarga besar. Tanggungan keluarga kecil adalah tanggungan yang terhitung sebanyak 1-3 orang sedangkan tanggungan keluarga besar adalah melebihi dari 3 orang.

Tabel 4. Pengalaman Berdagang Responden

\begin{tabular}{ccc}
\hline $\begin{array}{c}\text { Pengalaman } \\
\text { Berdagang } \\
\text { (Tahun) }\end{array}$ & $\begin{array}{c}\text { Jumlah } \\
\text { Responden } \\
\text { (Orang) }\end{array}$ & $\begin{array}{c}\text { Presentase } \\
(\%)\end{array}$ \\
\hline $1-3$ & 2 & 20 \\
$4-7$ & 8 & 80 \\
Jumlah & 10 & 100 \\
\hline
\end{tabular}

Sumber : Data Primer Diolah (2020).

Berdasarkan tabel 4 diatas, dapat diketahui bahwa sebagian besar responden yang memiliki pengalaman berdagang 1-3 tahun yaitu sebanyak 2 orang responden (20\%) sedangkan yang memiliki pengalaman berdagang 4-7 tahun yaitu sebanyak 8 orang responden $(80 \%)$. Pengalaman berdagang merupakan lamanya pedagang berkarya pada usaha perdagangan yang sedang dijalani saat ini. Lamanya suatu usaha dapat menimbulkan pengalaman berusaha, dimana pengalaman dapat mempengaruhi pengamatan seseorang dalam bertingkah laku (Sukirno, 2006). Ketika semakin lama seseorang menjalankan usahanya maka akan semakin berpengalaman orang tersebut. Sedangkan pengalaman kerja itu sendiri merupakan proses pembentukan pengetahuan atau keterampilan tentang metode suatu pekerjaan karena keterlibatan dalam pelaksanaan tugas pekerjaan (Manulang, 1984).

3. Analisa Pendapatan Penjual Daging Ayam Broiler Di Pasar Sila

Tabel 5. Rata-rata Biaya Tetap Penjual Daging Ayam Broiler Di Pasar Sila

\begin{tabular}{cc}
\hline Biaya Tetap & Rata-Rata(Hari/Bulan) \\
\hline Sebelum Pandemi & Rp. 35.525 .000 \\
Sesudah Pandemi & Rp. 39.095 .000
\end{tabular}

Sumber : Data Primer Diolah (2020).

Berdasarkan tabel 5 diatas, dapat diketahui biaya tetap sebelum pandemi yaitu sebanyak Rp. 35.525.000 /bulan sedangkan biaya tetap sesudah pandemi yaitu sebanyak Rp. 39.095.000/bulan. Biaya tetap adalah biaya yang nilainya akan tetap dan konstan walaupun terjadi perubahan pada proses produksi. Biaya tetap meliputi biaya lapak, biaya beli ayam, biaya kebersihan dan keamanan.

Tabel 6. Rata-rata Biaya Tidak TetapPenjual Daging Ayam Broiler Di Pasar Sila

\begin{tabular}{cc}
\hline Biaya Tidak Tetap & Rata-Rata (Hari/Bulan) \\
\hline Sebelum Pandemi & Rp. 510.000 \\
Sesudah Pandemi & Rp. 690.000 \\
\hline
\end{tabular}

Sumber : Data Primer Diolah (2020).

Berdasarkan tabel 6 diatas, dapat diketahui biaya tidak tetap sebelum pandemi yaitu sebanyak Rp. 510.000/bulan sedangkan biaya tidak tetap sesudah pandemi yaitu sebanyak Rp. 690.000/bulan. Biaya tidak tetap adalah biaya yang nilainya dapat berubah-ubah per unit nya. Biaya tidak tetap meliputi biaya parkir dan biaya tenaga kerja.

Tabel 7. Rata-rata Biaya Total Penjual Daging Ayam Broiler Di Pasar Sila

\begin{tabular}{cc}
\hline Biaya Total & Rata-Rata (Hari/Bulan) \\
\hline Sebelum Pandemi & Rp. 36.035.000 \\
Sesudah Pandemi & Rp. 39.785.000 \\
\hline Sumber : Data Primer Diolah (2020). \\
Berdasarkan Tabel 7 diatas, dapat \\
diketahui biaya total sebelum pandemi yaitu \\
sebanyak Rp. 36.035.000/bulan sedangkan \\
penjualan sesudah pandemi yaitu sebanyak \\
Rp. 39.785.000/bulan.
\end{tabular}


Tabel 8. Rata-rata Pendapatan Kotor Penjual Daging Ayam Broiler Di Pasar Sila

\begin{tabular}{lc}
\hline Pendapatan Kotor & Rata-Rata (Hari/Bulan) \\
\hline Sebelum Pandemi & Rp. 43.335 .000 \\
Sesudah Pandemi & Rp. 48.780.000 \\
\hline Sumber : Data Primer Diolah (2020). \\
Berdasarkan tabel 8 diatas, dapat \\
diketahui pendapatan kotor penjualan ayam \\
broiler sebelum pandemi yaitu sebanyak Rp. \\
43.335.000/bulan sedangkan pendapatan \\
kotor ayam broiler sesudah pandemi yaitu \\
sebanyak Rp. 48.780.000/bulan. Pada \\
Penelitian (Kholik. Dkk, 2017) bahwa \\
pendapatan petani secara bersama \\
dipengaruhi oleh sharing pengetahuan, \\
kerjasama, peningkatan motivasi, dan \\
perubahan perilaku, dengan adanya faktor \\
maka pendapatan peternak bisa dipengaruhi \\
dari beberapa faktor tersebut.
\end{tabular}

Tabel 9. Rata-rata Pendapatan BersihPenjual Daging Ayam Broiler Di Pasar Sila

\begin{tabular}{cc}
\hline $\begin{array}{c}\text { Pendapatan } \\
\text { Bersih }\end{array}$ & Rata-Rata (Hari/Bulan) \\
\hline Sebelum Pandemi & Rp. 7.300 .000 \\
Sesudah Pandemi & Rp. 8.915.000 \\
\hline
\end{tabular}

Sumber : Data Primer Diolah (2020).

Berdasarkan tabel 9 diatas, dapat diketahui pendapatan bersih ayam broiler sebelum pandemi yaitu sebanyak Rp. 7.300.000/bulan sedangkan pendapatan bersih ayam broiler sesudah pandemi yaitu sebanyak Rp. 8.915.000/bulan. Pendapatan penjual ini sebenarnya dipengaruhi juga dengan pendapatan rumah tangga karena pengeluaran rumah tangga dipengaruhi oleh Pendapatan rumah tangga (Fikriman. Dkk, 2020), sehingga tingkat daya beli dipengaruhi dari pendapatan penduduk.

Tabel 10.Rata-rata BEP Produksi Penjual Daging Ayam Broiler Di Pasar Sila

\begin{tabular}{cc}
\hline BEP Produksi & Rata-Rata (Hari/Bulan) \\
\hline Sebelum Pandemi & 800 \\
Sesudah Pandemi & 663 \\
\hline Sumber
\end{tabular}

Sumber : Data Primer Diolah (2020).

Berdasarkan tabel 10 diatas, dapat diketahui BEP produksi ayam broiler sebelum pandemi yaitu sebanyak 800 ekor/bulan sedangkan BEP produksi ayam broiler sesudah pandemi yaitu sebanyak 663 ekor/bulan.

Tabel 11. Rata-rata BEP Harga Penjual Daging Ayam Broiler Di Pasar Sila

\begin{tabular}{|c|c|}
\hline BEP Harga & Rata-Rata (Hari/Bulan) \\
\hline Sebelum Pandemi & Rp. 1.076 .510 \\
\hline Sesudah Pandemi & Rp. 1.387 .793 \\
\hline
\end{tabular}

Sumber : Data Primer Diolah (2020).

Berdasarkan tabel 11 diatas, dapat diketahui BEP harga ayam broiler sebelum pandemi yaitu sebanyak Rp. 1.076.510/bulan sedangkan BEP harga ayam broiler sesudah pandemi yaitu sebanyak Rp. 1.387.793/bulan.

\section{Kesimpulan dan Saran}

Kesimpulan yang dapat ditarik berdasarkan hasil dan pembahasan yaitu pendapatan penjual daging ayam broiler sesudah pandemi di Pasar Sila Kabupaten Bima masih dalam kondisi baik, sehingga dapat dikatakan bahwa usaha penjual daging ayam broiler berada pada posisi yang menguntungkan dan tidak memberikan dampak signifikan. Pendapatan bersih ayam broiler sebelum pandemi yaitu sebanyak Rp.7.300.000/bulan dan pendapatan bersih ayam broiler sesudah pandemi yaitu sebanyak Rp. 8.915.000/bulan. Hasil perhitungan BEP harga ayam broiler sebelum pandemi yaitu sebanyak Rp.1.076.510/hari, sedangkan BEP harga ayam broiler sesudah pandemi yaitu sebanyak Rp. 1.387.793/hari.

Diharapkan kepada pemerintah dan dinas terkait serta petugas melakukan sosialisasi dan pembaharuan informasi secara rutin yang berkaitan dengan penjualan ayam broiler pada saat pandemi Covid-19 ini. Mengingat hal ini tidak hanya berdampak pada prospek pasar tetapi juga berdampak pada kesehatan manusia serta diharapkan kepada penjual maupun pembeli di Pasar Sila untuk selalu mematuhi penerapan prokes dalam usaha meminimalisir penularan dan terbentuknya kluster baruCovid-19.

\section{Daftar Pustaka}

Badan Pusat Statistik (BPS). 2018.Peran Kemitraan Terhadap Pendapatan 
PeternakAyamBroiler.Kab.Bima.

Balai Besar Pengujian Obat dan MakananNTB (BPOM NTB). 2021. Survei Pasar Sila Kabupaten Bima sebagai Pasar Aman BerbasisKomunitas.http://puspaman.p om.go.id/

Departemen Kesehatan RI. 2009. Kategori Usia. Http://Kategori-Umurmenurut Depkes.

Fikriman, F., Budiman, F. A., \& Afrianto, E. (2020). Faktor Sosial Ekonomi yang Mempengaruhi Pengeluaran Pangan Rumah Tangga Miskin di Kecamatan Bangko Kabupaten Merangin. JAS (Jurnal Agri Sains), 4(2), 149-161.

Kementerian Perdagangan RI. 2020. Peraturan Menteri Perdagangan Republik Indonesia Nomor 7 Tahun 2020 Tentang Harga Acuan Pembelian di Tingkat Petani dan Harga Acuan Penjualan di Tingkat Konsumen.

Kholik, A., Susilawati, W., \& Fikriman, F. (2017). Pengaruh Faktor Sosial Dalam Kelompok Tani Terhadap Pendapatan Usahatani Kacang Panjang (Vigna Sinensis L) di Kecamatan Tabir Lintas Kabupaten Merangin. JAS (Jurnal Agri Sains), 1(2).

Manulang.1984. Manajemen Personalia. Jakarta: Ghalia Indonesia.

Notoatmodjo, S. 2012. Promosi Kesehatan dan Perilaku Kesehatan. Jakarta: PT. RinekaCipta.

Nugroho, Agung. 2008. Pengaruh Pendidikan, Disiplin dan Lingkungan KerjaTerhadap Produktivitas KerjaKaryawan pada PT. Kudus Karya Prima.UniversitasMuria Kudus.tidak dipublikasikan.

Rangkuti, K., Siregar, S., Thamrin, M. dan Andriano,R. 2014. Pengaruh Faktor SosialEkonomiTerhadap Pendapatan Petani Jagung. J.Agrium. 19(1).52-58.

Roestam, A.W. 2003. Pelatihan Aplikasi Ergonomi untuk Produktivitas. Jakarta: Ilmu Kedokteran Komunitas.
FKUI.

Rosyidi.Suherman.2001. Pengantar Teori Ekonomi (Pendekatan Kepada Teori Ekonomi Mikro dan Makro.)PenerbitPT. Raja Grafindo Persada, Jakarta.

Soekartawi. 2006. Analisis Usaha Tani. Jakarta: UI Press.

Syarifuddin, A. Kasim. 1995. PengantarEkonomi Produksi. Fakultas Pertanian Unlam. Banjarbaru.

Sukirno, Sadono. 2006. Teori Pengantar Ekonomi Mikro. Jakarta: PT. Raja Grafindo Persada.

WHO.2020. WHODirector-General's Remarks At The Media Briefing On 2019-nCov on 11 February 2020. 